\title{
Proximate Analysis and Phytochemical Screening of Watermelon (Citrullus lanatus) Pulp, Peels and Seeds
}

\author{
'Sadiq Ismaila Shina, 'Saminu Murtala Yakasai, 'Zainab Lawal, \\ ${ }^{2}$ Adeleye Adeniyi Olarewaju, 'Sanni Lawal Enesi, ${ }^{3}$ Dandalma Zainab Ali. \\ 1. Department of Chemistry, \\ Faculty of Science, \\ P.M. B 7156. \\ Federal University Dutse \\ Jigawa State, Nigeria. \\ 2. Department of Environmental Sciences, \\ Faculty of Science, \\ P.M.B 7156 \\ Federal University Dutse \\ Jigawa State, Nigeria.
}

3. Department of Biotechnology, Faculty of Science, P.M.B 7156 Federal University Dutse Jigawa State, Nigeria.

Email: shinasadiq2015@gmail.com

\begin{abstract}
The fruit popularly known as Watermelon (Citrullus lanatus) is a local recipe eaten in Nigeria and African. The research was conducted to evaluate the nutritional composition and phytoconstituents of the peels, pulp and seeds of the fruit. The vitamin $C$ was also determined. Proximate analysis revealed that the pulp contained much higher moisture content of $11.50 \pm 0.50 \%$ than the peels with $8.78 \pm$ $1.25 \%$, and $3.66 \pm 0.29 \%$ seed respectively. The ash content for peels was high with $5.31 \pm 0.55 \%$, while pulp contained $3.66 \pm 0.82 \%$ and the seeds contained $2.97 \pm 05 \%$ respectively. For crude lipids; seeds contained high value of $13.66 \pm 0.29 \%$ compared to the peels with $2.33 \pm 0.29 \%$ and pulp contained $0.5 \pm 0.00 \%$.respectively. The crude fibre; seeds contained higher value of $14.66 \pm 0.57$ $\%$ compared to peels with $10.66 \pm 29 \%$ and7.66 $\pm 0.29 \%$ for pulp. The crude proteins, the peels contained $2.88 \pm 1.69 \%$, while the pulp contained $3.33 \pm 0.17 \%$ and seeds contained $18.75 \pm 0.65 \%$ having the highest value which implies that the seed is rich in protein thereby help to build the body and replace worn-out tissues. The carbohydrate value for pulp was much higher with $73.35 \pm 1.78 \%$, peels contained $70.04 \pm 4.05 \%$ and seed contained $46.3 \pm 0.78 \%$ respectively. The mineral elements revealed that $\mathrm{Na}, \mathrm{K}, \mathrm{Ca}, \mathrm{Mg}, \mathrm{Fe}, \mathrm{P}$ and $\mathrm{Zn}$ are much present with significant different $P<0.05$. Therefore, seed is a reservoir of crude lipids, while pulp serves as a reservoir of moisture content and food supplement whereas peels serve as reservoir for mineral elements. The vitamin $C$ value ranged from (4.56 0.47 to $3.32 \pm 0.37) \mathrm{mg} / 100 \mathrm{~g}$ respectively. Phytochemical analyses of aqueous extracts revealed that terpenoids, saponins, alkaloids, cardiac glycosides and steroids are present. This justify the claim why the fruit can be used as food and medicinal purpose.
\end{abstract}

Keywords: Citrullus lanatus, Minerals, Proximate analysis, Phytoconstituents, Watermelon 


\section{INTRODUCTION}

Proximate analysis refers to the determination of the major constituents of lignocellulosic biomass materials. Principally, the process involves determination of carbohydrate contents, moisture, ash, crude fiber, crude protein, ether extract and Nitrogen- free extract of the biomass. The energy building food (Carbohydrates) are plant products which are formed as major by-products of photosynthetic pathway. They are eaten by man and animals as the major source of energy (Choudhary et al., 2015). This is hydrolyzed in the body to yield glucose which can be used immediately, or stored as glycogen in the muscles and liver for future use (Choudhary et al., 2015). When they are eaten in excess of the body requirement, it is converted to fat and stored in the adipose tissue under the skin (Choudhary et al., 2015).

However dietary fats the fat-soluble vitamins and essential fatty acids contained in the fat of natural foods. Fats and oils help to control blood pressure and play useful role. Water content is a universal solvent which is soluble in other substances, carries nutrients and other materials throughout the body, making it possible for every organ to perform its function effectively (Megan, 2019).

Another useful part is crude fibers which are parts of fruits, grains and vegetables that can neither be digested nor absorbed by the human system. Therefore, dietary fiber help in the body to reduce the rate of glucose absorption into the blood stream, reducing the risk of hyperglycemia (Choudhary et al., 2015). They decrease the levels of cardiovascular diseases, plasma cholesterol and prevent colon cancer. While the ash content of a plant food is the function of the mineral elements present (Sadiq et al., 2013). Plant Dietary ash has revealed useful in establishing and maintaining acid-alkaline balance of the blood system in regulating hyperglycaemia condition. Some vitamin precursors that are produced, vitamin C, B and carotene, like polyphenols are strong anti-oxidants. This antioxidants prevent structural changes caused by oxidation, will help fend off diseases such as cardiovascular disease (Asils et al.1985; El-Adawy and Taha, 2001).

The plant under investigation belongs to the family of Cucurbitaceae commonly referred to as gourd and called "kankana" in Hausa. It is flowering plant originated in West Africa and is one of the common cultivated fruit in African having more than one thousand varieties. Watermelon is around $90 \%$ water, which makes it useful for staying hydrated in the summer. It can also satisfy a sweet tooth with its natural sugars (Warri et al., 2011). Watermelon also contains antioxidants. These substances can help remove molecules known as free radicals, or reactive species from the body. The body produces free radicals during natural processes, such as metabolism. They can also develop through smoking, air pollution, stress, and other environmental pressures. If too many free radicals stay in the body, oxidative stress can occur. This can result in cell damage and may lead to a range of diseases, such as cancer and heart disease. The body can remove some free radicals naturally, but dietary antioxidants support this process (Choudhary et al., 2015).

Watermelon fruit can be classified into three major parts which are the rind (peel), pulp and seeds respectively. Watermelon constitutes approximately $68 \%$ flesh, the rind $30 \%$ and the seed $2 \%$ of the total fruit weight. Scientific evidences have shown that watermelon contains vitamin $C$ which is an essential nutrient for humans because it aids in the synthesis of collagen in addition to protecting against oxidative damage. However, watermelon extract is recommended to formulate cosmetic products at protecting the hair integrity and skin against oxidative process (Kiin-Kabari and Kusu, 2014).

The useful process of these natural phytochemicals are terpenoids, carotenoids, flavonoids, steroids, alkaloids, tannins and glycosides are antibiotic principles of plants (Ajayi et al., 
2011). They are usually distributed in plants, yet these compounds were not well established due to the lack of knowledge and techniques (Hafiza et al., 2002; Sadiq et al., 2016). These phytochemicals have been reported to exhibit foaming activity, antifungal property, hemolytic and anti-inflammatory (Ajayi et al., 2011). There has been a keen interest in search for phytochemicals of naturalized plants for nutritional purposes and pharmaceutical (Wani et al., 2004). This recognition that plant-derived products have good potential as sources of pharmaceuticals (Borchardt et al., 2008). Although roots, flowers, leaf and whole plants, and stems were examined for useful phytochemicals in many research projects, few reports referred to seeds as sources for pharmaceuticals (Borchardt et al., 2008). The purpose of this research work was to determine the proximate analyses and phytochemical analyses of watermelon peels, pulp and seeds respectively.

\section{Materials and Methods}

The study area is in Dutse Local Government Area, Dutse emirate Jigawa State Nigeria. Which is located between Latitudes $11^{\circ} 38^{\prime} 31^{\prime \prime} \mathrm{N}$ and $11^{\circ} 46^{\prime} 16^{\prime \prime} \mathrm{N}$ and longitudes $9018^{\prime} 33^{\prime \prime} \mathrm{E}$ and 9024' 24 'E. with estimated population of 138,451, this comprises of 68,975 males and 69,476 females (NPC, 1991). According to the 2006 census, Dutse has a population of 251,135, people living in the area, with 125,773 male and 125,362 females (NPC, 2006). The climate of Dutse is tropical wet dry climate (Koppen AW) classification and the temperature is warm to hot throughout the year, even though there is slightly cool period around November through February. The mean annual temperature is $26^{\circ} \mathrm{C}$ but, mean monthly value ranges between $21^{\circ} \mathrm{C}$ in the coldest months (February) and $31^{\circ} \mathrm{C}$ in the hottest months (April/May) (Aminu, 2015)

\section{Collection of Samples and Identification}

The riped watermelon fruits was obtained from Dutse Central Market Jigawa State, Nigeria on 20th May, 2021 and transported to the Herbarium Unit where it was identified by a botanist, Department of Biological Sciences, Faculty of Science, Federal University Dutse, Jigawa State for identification.

\section{Preparation of Watermelon}

Watermelon fruits were sliced to remove the peels, flesh and seeds separately. The rinds were washed and left to dry at ambient temperature. The colored part of the fruit's peels was carefully scrapped to reduce the inclusion of albedo- an inner layer of spongy white tissue. The fresh peels were further dried at $50^{\circ} \mathrm{C}$, cooled and then grinded to a fine powder. The seeds were also dried indoors and grinded to fine powder.

\section{Proximate Analysis of the Watermelon}

The proximate analyses of watermelon pulp or flesh, peels and the seeds were conducted in the Chemistry laboratory, Faculty Science Federal University Dutse, Jigawa State, Nigeria, adopting the methods by Association of Official Analytical Chemist (AOAC, 1990; AOAC, 2005). Methods are outlined as follows:

\section{Determination of Moisture Content}

Clean aluminum dish was dried at a temperature of $105^{\circ} \mathrm{C}$ for a period of one hour in an oven after which it was cooled in a desiccator. An empty aluminum dish was then weighed (W1). The dish was reweighed (W2) after adding $2 \mathrm{~g}$ of the sample was returned to the oven where it was allowed to dry to a constant weight at a temperature of $105{ }^{\circ} \mathrm{C}$. The dish was removed, cooled in a desiccator and reweighed (W3). The percent moisture content of the sample was calculated from equation (1). 
$\%$ moisture content $=\frac{\mathrm{W} 2-\mathrm{W} 1}{\mathrm{~W} 3-\mathrm{W} 1} \times 100 \%$

The percent dry matter is therefore obtained using equation (2).

$\%$ Dry matter of sample $=(100-\%$ moisture content of sample

\section{Determination of Ash Content}

Crucible container was well cleaned and weighed (W1). Two grams (2 g) of the pretreated watermelon samples powder transfer into the crucible and reweighed (W2). The crucible containing the sample was transfer in a furnace set at $600{ }^{\circ} \mathrm{C}$, and was allowed to stay for a period of 10 hours; long enough for the sample to turn to a whitish-grey ash after which it was allowed to cool. The ash was then reweighed (W3). Similar procedure was carried out on the watermelon seeds. The percentage ash content of the samples was calculated based on equation (3).

$\%$ Ash $($ dry basis $)=\frac{\mathrm{W} 3-\mathrm{W} 1}{\mathrm{~W} 2-\mathrm{W} 1} \times 100 \%$

Where: $\mathrm{W} 1=$ weight of empty crucible

W2 = weight of empty crucible + sample before ashing,

W3 $=$ weight of crucible ash in grams .

\section{Determination of Crude Protein}

Crude protein content of the samples was analyzed using Kjeldahl tablet. Two grams (2 g) of the samples were weighed into the digestion tube and 2 Kjeldahl tablets and $20 \mathrm{~mL}$ of concentrated sulphuric acid $\left(\mathrm{H}_{2} \mathrm{SO}_{4}\right)$ was added into the tube and digested at $420{ }^{\circ} \mathrm{C}$ for 5 hours. Upon cooling, $90 \mathrm{ml}$ of distilled water was added into the digested solution. About 50 $\mathrm{mL}$ of $40 \%$ caustic soda $(\mathrm{NaOH})$ was added in the solution, and then placed on a heating section of a distillation chamber. $30 \mathrm{~mL}$ of $4 \%$ boric acid plus bromocresol green and methyl red indicator was put into conical flask and placed underneath the distillation chamber for collection of ammonia. The solution changed from orange to green colour. A burette was filled with $0.1 \mathrm{M}$ solution of hydrochloric acid $(\mathrm{HCl})$, the solution in the conical flask was titrated with the acid until the color changed from green to pink. The burette reading was recorded and the crude protein $(C p)$ was determined based on equation (4):

$\% C p=\frac{(\mathrm{A}-\mathrm{B}) \times \mathrm{M} \times \mathrm{F} \times 6.250}{\mathrm{mg} \text { of samples }} \times 100 \%$

Where $\mathrm{A}=\mathrm{mL}$ of acid used for titrating the sample, $\mathrm{B}=\mathrm{mL}$ of acid used for titrating blank sample $(O) ; \mathrm{M}=$ Molar concentration of acid used for titration; $\mathrm{F}=$ Factor $=14.007 ; 6.25=$ constant.

\section{Determination of Crude Fiber}

The crude fiber of the samples was determined by weighing $2 \mathrm{~g}$ of the samples and then placed in a round bottom flask onto which $50 \mathrm{~mL}$ of tri-chloroacetic acid reagent (TCA) was added. Then mixture was boiled and refluxed for 40 minutes. It was allowed to cooled at room temperature and using a filter paper to separate residue. The residue was washed four (4) times with hot water and once with petroleum ether. The filter containing the residue was packed together and dried at $50{ }^{\circ} \mathrm{C}$ in an oven for 24 hours. The sample was weighed and then ash at $650 \circ \mathrm{C}$ and was cooled and weighed, percentage crude fiber was determined using equation (5):

$\%$ Crude Fibre $=\frac{\text { difference in weighing }}{\text { weight of sample on dry matter basis }} \times 100 \%$

$\% \mathrm{CF}=\frac{W 2-W 3}{W 1} \times 100 \%$ 


\section{Determination of Crude Lipid}

Crude lipid was carryout with the help of Soxhlet extractor. Two grams of sample was weighed and transferred to a thimble and $200 \mathrm{~mL}$ of petroleum ether was poured into round bottom flask and was heated at $45{ }^{\circ} \mathrm{C}$ for 3 hours. The flask was removed and cooled for 15 minutes and percentage crude lipid was determined using equation (6).

$\%$ Fat $=\frac{\text { Weight of fat }}{\text { weight of sample }} \times 100 \%$

\section{Determination of Carbohydrate Content}

Percentage carbohydrate of the samples was also computed using the equation (7).

$\%$ Carbohydrate $=100-(\%$ Ash content $+\%$ C. Lipid $+\%$ C. fibre + C. protein $) \ldots . . .(7)$

\section{Determination of Energy Content}

The energy content was obtained based on the formular depicted in equation 8

Energy $=($ protein X 2.44 $)+($ lipid X 8.37 $)+($ CHO X 350 $)$

\section{Elemental Analysis}

The analyses was carried out in triplicates and reported as mean \pm standard deviation, dry weight (DW). Mineral analyses was carried out after wet digestion of two grams of each powder sample (peels, pulp and seeds) with nitric/perchloric/sulphric acid in the ratio (9:2:1) mixture, while phosphorus was determined colorimetrically with a Jenway 6100 spectrophotometer using phosphorus vanadomolybdate. Meanwhile Magnesium and Calcium were determined by EDTA method while Potassium and Sodium was analysed with a Corning 400 Flame photometer. Iron and Zinc were analyzed by Atomic Absorption Spectroscopy (AAS) with standard air-acetylene flame (AOAC, 1990; AOAC, 2005).

\section{Vitamin C Determination}

Vitamin $\mathrm{C}$ was determined by dissolving $3 \mathrm{~g}$ of each sample in $2 \mathrm{~cm}^{3}$ of $10 \%$ glacial acetic acid and blended for 10 minutes and filtered. Then residue was later washed with $5 \mathrm{~cm}^{3}$ portion of $10 \%$ glacial acetic acid. $60 \mathrm{~cm}^{3}$ of $0.3 \mathrm{M} \mathrm{H}_{2} \mathrm{SO}_{4}$ was added followed by the addition of $2 \mathrm{~g}$ solid potassium iodide and $25 \mathrm{~cm}^{3}$ of $0.01 \mathrm{M}$ potassium iodate followed by $25 \mathrm{~cm}^{3}$ of the filterate was titrated with $0.07 \mathrm{M}$ sodium Thiosulphate solution (AOAC,1990).

\section{Results}

The results of the nutritional composition and phytoconstituents for peels, pulp and seeds of Citrullus lanatus are presented in Tables 1, 2 and 3 respectively.

Table 1: Proximate Analyses of Peels, pulp and Seeds of Citrullus lanatus

\begin{tabular}{llll}
\hline Parameters (\%) & Peels & Pulp & Seeds \\
\hline Moisture content (FW) & $8.78 \pm 1.25$ & $11.50 \pm 0.50$ & $3.66 \pm 0.29$ \\
Ash Content & $5.31 \pm 0.55$ & $3.66 \pm 0.82$ & $2.97 \pm 0.05$ \\
Crude Lipid & $2.33 \pm 0.29$ & $0.5 \pm 0.00$ & $13.66 \pm 0.29$ \\
Crude Fibre & $10.66 \pm 0.29$ & $7.66 \pm 0.29$ & $14.66 \pm 0.57$ \\
Crude protein & $2.88 \pm 1.67$ & $3.33 \pm 0.17$ & $18.75 \pm 0.62$ \\
Carbohydrate & $70.04 \pm 4.05$ & $73.35 \pm 1.78$ & $46.3 \pm 0.78$ \\
Vitamin C (mg/100g) & $3.57 \pm 0.43$ & $4.56 \pm 0.47$ & $3.32 \pm 0.37$ \\
Energy (KJ/Mol) & $276.56 \pm 1.67$ & $274.17 \pm 1.29$ & $325.371 \pm 2.0$ \\
\hline
\end{tabular}

Mean \pm Standard deviation (SD) of triplicate analyses, mean in the same row are significantly different, $\mathrm{P}<0.05, \mathrm{FW}=$ Fresh weight. 
Table 2: Mineral Composition of Watermelon Citrullus lanatus

\begin{tabular}{llll}
\hline Elements $(\mathrm{mg} / \mathrm{kg})$ & Peels & Pulp & Seeds \\
\hline $\mathrm{Na}$ & $1.16 \pm 0.95$ & $0.38 \pm 0.06$ & $0.32 \pm 0.03$ \\
$\mathrm{Mg}$ & $8.22 \pm 0.19$ & $6.14 \pm 0.22$ & $4.38 \pm 0.02$ \\
$\mathrm{Ca}$ & $28.70 \pm 0.2$ & $26.30 \pm 0.08$ & $23.33 \pm 0.40$ \\
$\mathrm{~K}$ & $4.83 \pm 0.06$ & $3.63 \pm 0.06$ & $2.97 \pm 0.06$ \\
$\mathrm{P}$ & $5.17 \pm 0.03$ & $3.70 \pm 0.1$ & $2.36 \pm 0.06$ \\
$\mathrm{Fe}$ & $0.28 \pm 0.07$ & $0.21 \pm 0.07$ & $0.16 \pm 0.01$ \\
$\mathrm{Zn}$ & $19.80 \pm 1.04$ & $13.60 \pm 0.58$ & $7.50 \pm 1.27$ \\
\hline
\end{tabular}

Mean \pm Standard deviation (SD) of triplicate analyses. Mean in the same row are significantly different,

Table 3: Phytochemical Constituents of Watermelon- Citrullus lanatus

\begin{tabular}{llll}
\hline Phytochemicals & Peels & pulp & Seeds \\
\hline Alkaloids & ++ & - & + \\
Saponins & ++ & +++ & - \\
Tannins & - & - & - \\
Flavonoids & - & - & ++ \\
Carbohydrate & ++ & ++ & ++ \\
Steroids & -- & -- & +++ \\
Cardiac Glycosides & +++ & -- & + \\
Terpenoids & + & + & + absent,
\end{tabular}

\section{DISCUSSION}

Results generated from the comparison of the peels, seeds and pulp of the analyzed watermelon indicated that the pulp had much higher moisture content of $11.50 \pm 0.50 \%$ than the peels which had moisture content of $8.78 \pm 1.25 \%$, followed by the seeds which had the least moisture content of $3.66 \pm 0.29 \%$ (Table 1). However, it implies that the pulp has a low shelf life compared to the peels and seeds. Previous research revealed that the moisture content of watermelon seeds flour as seed kernel and coat was 4.58, 4.22 and 5.92\% respectively (Hassan, 1998),

The ash content is the inorganic content of mineral that does not volatize after subjecting the sample to high temperature. The ash content of peels was high having value of $5.31 \pm 0.55 \%$, whereas the pulp contained $3.66 \pm 0.82 \%$ while the seeds contained $2.97 \pm 0.05 \%$ respectively. This implies that the peels was high in mineral elements based on the present work. These results agrees with the report of Mustafa et al., (1972) who indicate that the ash content of watermelon seed was $2.6 \%$, while it was also revealed that the ash content of watermelon seeds analysed as a whole seed, and kernel in their study was 2.84 and $2.71 \%$ (Das et al., 2002).While Hassan (1998) reported that the ash content of the kernel and coat of seeds were 2.7 and $1.6 \%$ respectively. The present study revealed that the seeds contained high value of crude lipid/fat which was $13.66 \pm 0.29 \%$ compared to the peels which contained $2.33 \pm 0.29$, whereas pulp contained $0.5+0.00 \%$. These results are slightly contrary to the report of Hassan (1998) who found out that the kernel of watermelon seeds contained high level of oil $(50.36 \%)$, while the seed coat was $2.738 \%$. this may be attributed to the method of extraction and the soil where the watermelon was collected. A study conducted by Mustafa et al. (1972) revealed that the fat content of seed and kernel were 25.87 and $50.64 \%$, respectively. It was also reported that the oil content of two varieties of seeds "Bara and Serewe" were 54.2 and 56.9\%, respectively (Oyenuga et al., 1975; Godwin et al., 2008). The percentage composition of crude fibre for (peels, pulp and seeds), the seeds was higher contains $14.66 \pm 0.57 \%$ compared to the peels which contained $10.66 \pm 29 \%$. This was 
followed by the pulp which contained least value of $7.66 \pm 0.29 \%$. This implies that the seed will help to improve the bowel activity of the stomach.

However, with regards to crude protein, the peel contained $2.88 \pm 1.69 \%$, while the pulp contained $3.33 \pm 0.17 \%$ and seeds contained $18.75 \pm 0.65 \%$ have the highest value which implies that the seed is rich in protein thereby help to build the body and replace worn-out tissues According to FAO (1988), kernel contained about 38\% protein which is in agreement with Hassan (1998) who found that the protein content of the watermelon seed was $38.10 \%$ for the kernel and $21.3 \%$ for the whole seed, but it was reported that $0.64 \%$ for the seed coat, while it was reported that the protein content of watermelon seeds for two Nigerian varieties (Bara/Serewe) were $35.7 \%$ and $30.6 \%$ respectively (Oyenuga et al., 1975). The carbohydrate value for pulp was much higher with $73.35 \pm 1.78 \%$, while peels contained $70.04 \pm 4.05 \%$ and seed contained $46.3 \pm 0.78 \%$ respectively. This implies that the pulp is very rich in energy. However carbohydrate generally are energy giving food (Sadiq et al., 2016). The Vitamin C content for peels contained $3.57 \pm 0.43 \%$, pulp contained $4.56 \pm 0.47 \%$ and seed contained $3.32 \pm 0.37 \%$ respectively. This implies that the pulp is rich in vitamin $C$ thereby helping to prevent scurvy in children and oxidative activity in man (Adesanya et al., 2011; Sadiq et al., 2013).

Therefore, result of mineral elements for peels revealed that sodium contained $1.164 \pm 0.95$ $\mathrm{mg} / \mathrm{kg}$ was found to be high, as such, there was no much difference in sodium content between the peels, pulp and seed. While result also showed that magnesium was high in the peels with $8.22 \pm 0.19 \mathrm{mg} / \mathrm{kg}$ compared to pulp $6.14 \pm 0.22 \mathrm{mg} / \mathrm{kg}$ and seeds $4.38 \pm 0.22$ $\mathrm{mg} / \mathrm{kg}$ respectively. This implies that the peel is rich in magnesium which is necessary for the formation of bones. The values of calcium ranges from $23.30 \pm 0.8 \mathrm{mg} / \mathrm{kg}$ to $28.70 \pm 0.2$ $\mathrm{mg} / \mathrm{kg}$. This also implies that the peels will help in formation of strong bones and teeth development. Also, comparing the concentration of potassium, the peels contained higher concentration of potassium compared to the pulp and seeds which ranges from $2.97 \pm 0.06$ $\mathrm{mg} / \mathrm{kg}$ to $4.83 \pm 0.06 \mathrm{mg} / \mathrm{kg}$. This will also assist in increasing the level of ions concentration in the body.

The value for $\mathrm{P}$ content revealed that the peels also contained the highest concentration ranges from $2.36 \pm 0.06 \mathrm{mg} / \mathrm{kg}$ to $5.17 .97 \pm 0.03 \mathrm{mg} / \mathrm{kg}$. While the values for iron revealed that peels contained the highest value $0.28 \pm 0.07 \mathrm{mg} / \mathrm{kg}$, pulp contained $0.21 \pm 0.07 \mathrm{mg} / \mathrm{kg}$ and seeds contained $0.16 \pm 0.07 \mathrm{mg} / \mathrm{kg}$. The zinc concentration revealed that the peels contained higher concentration compared to pulp and seeds. These results was favourably compared to work reported (Hassan,1998) that $\mathrm{K}, \mathrm{Ca}, \mathrm{Mg}, \mathrm{Na}, \mathrm{Mn}, \mathrm{Fe}$ and $\mathrm{Cu}$ of watermelon seed kernel were $53,0.68,28,105,0.14,1.87$ and $0.86 \mathrm{mg} / \mathrm{kg}$, respectively, while El-Adawy and Taha (2001) revealed that flour contains considerable value of $\mathrm{P}, \mathrm{K}, \mathrm{Mg}, \mathrm{Mn}$ and Co. The purpose of using oil seed meals as alternative protein sources for human consumption has received tremendous attention in past years (Hassan, 1998). The peel revealed the presence of alkaloids, saponins, carbohydrate, cardiac glycosides and terpenoids, while the pulp indicates the presence of saponins, while the seeds revealed the presence of alkaloids, carbohydrate, steroids, and cardiac glycosides respectively. These results implies that the presence of these phytoconstituents in watermelon indicate its medicinal value to man and also serve as food (Sadiq et al., 2016). Watermelon peel, much like watermelon flesh, is mostly made of water. The rind, that is the green skin that contains all that water-logged delicious fruit safe, is totally edible and because of presence of phytoconstituents; saponins, steroids, tannins, terpenoids etc. they are used as antifungal agent and antibacterial agent and boost the immune system (Braide et al., 2012 ; Sadiq et al., 2016). 


\section{CONCLUSION}

However the present research indicates that pulp is rich in carbohydrate and vitamin $C$ which justify its claim as being used as fruit and food supplement. However, the peels also from the analyzes indicates they are rich in mineral elements and peels indicates the presence of alkaloids, saponins, carbohydrate, cardiac glycosides and terpenoids, while the pulp indicate the presence of saponins and seeds of watermelon revealed the presence of alkaloids, carbohydrate, steroids, and cardiac glycosides respectively. These results implies that the presence of these phytoconstituents of watermelon is highly medicinal and also serve as food (Sadiq et al., 2016). Watermelon peel, much like watermelon flesh, is mostly made of water because of the presence of phytoconstituents; saponins, steroids, tannins, terpenoids used as antibacterial and antifungal agent and boost the immune system.

\section{RECOMMENDATION}

As a result of the present findings, the result available have revealed the peels are good source of mineral elements and phytoconstituents. Therefore, recommend that further work be done on the peels of watermelon in order to isolate and identified compounds present in the peels and possible determination of their antinutrient factors.

\section{REFERENCE}

Adesanya A. O, Olaseinde O. O, Oguntayo O.D, Otulana J.O. and Adefule A.K. (2011). Effects of Methanolic Extract of Citrullus lanatus Seed on Experimentally Induced Prostatic Hyperplasia. European Journal of Medicinal Plants, 1(4):171-179.

Ajayi I.A. Ajibade O and Oderinde R.A. (2011).Preliminary Phytochemical Analysis of some Plant Seeds. Res. J. Chem. Sci.1 (3): 58-62.

AOAC (2005). Official Method of Analysis, Association of Official Analytical Chemists. 18th ed. Gaithersburg, Maryland USA: AOAC International, pp.231-234.

AOAC, (1990). Official Method of Analysis, Association of Official Analytical Chemist, $4^{\text {th }}$ Edition Washington D.C. pp 96-108.

Asils, S. Kamel, Dawson, H.S. and Kakuda, Y. (1985).Characteristics and composition of melon and grape seed oils and cakes. J. Am. Oil Chem. Soc., 62 (5):881-884.

Aminu S. Z (2015), land use, land cover changes in Dutse (1986-2014), Jigawa state, Nigeria.

(Master's thesis). Department of Geography, Faculty of Science Ahmadu Bello University,

Zaria Nigeria.

Borchardt J. R., Wyse D. L., Sheaffer C.C, Kauppi K. L. R., Fulcher .G, Ehlke. N. J, Biesboer D. D, and Bey R. F., (2008). Antioxidant and Antimicrobial Activity of Seed from Plants of the Mississippi River Basin. J. Med. Plants Res. 2(4): 081-093

Braide W, Odiong IJ, Oranusi S (2012). Phytochemical and Antibacterial properties of the seed of watermelon (Citrullus lanatus). Prime Journal of Microbiology Research, 2(3), 99104.

Choudhary, B.R., Harlhar, S. M., Maheshwari, S. K., Bhargava, R. and Sharma, S, K. (2015). Phytochemicals and Antioxidants in water melon (Citrillus Lanatus) Genotypes under Hot Arid Region. Indian Journal of Agricultural Science, 85, 414-417.

Das, M.; Das, S.K. and Suthar, S.H. (2002). Composition of seed and characteristics of oil from karingda (Citrullus lanatus, Thumb, Mansf). International Journal Food Science Technology, 37:893-896.

EL-Adawy, T.A. and Taha, K.M. (2001). Characteristics and composition of watermelon, pumpkin and paprika seed oils and flours. Journal of Agricultural and Food Chemistry 49, 1253 - 1259.

Food and Agriculture Organization (FAO) Report, (1988). 
Giami, S. and Barber, L. (2005). Utilization of protein concentrates from ungerminated and germinated fluted pumpkin (Telfairia occidentalis Hook) seeds in cookie formulations. J. Sci. Fd Agric., 84:1901-1907.

Godwin C, Ojieh, M.O, Yetunde R.O, Kayode E.A, George, O.E, and Reginah T.O (2008). Compositional Studies of Citrullus lanatus (Egusi melon) Seed. The International Journal of Nutrition and Wellness ISSN: 1937- 8297.

Harbone, J.B. (1973). Phytochemical Methods; A guide to modern Technique of plant Analysis, Chapman and Hall, London pp 33-185.

Hafiza M.A, Parveen B, Ahmad R, Hamid K. (2002). Online Journal Biological Science 2: 130132.

Hassan, H.A. (1998). Biochemical and Technological Studies on Watermelon Seed Oil. M.Sc. thesis, University of Khartoum, Sudan.

Kiin-Kabari, D. B., Akusu, O. M. (2014): Effect of processing on the proximate composition, functional properties and storage stability of water melon (Citrullus Lanatus) seed flour. International Journal of Biotechnology Food Science. 2 (7), 143-148.

Megan, W.K. (2019). What are the health benefits of watermelon? Newsletter, medical news today.pp7-15.

Mustafa, A.E. Badi, S.M. Salama, R.B. Elsayed, A.S. and Hussein, A.A. (1972). Studies on watermelon seed oil. Sudan. Food Sci. Technol., 4:18-20.

National Population Commission (NPC).1991.Census Report.

Oyenuga, Y.A. and Fetuga, B.L. (1975). Some Aspects of the Biochemistry and Nutritive Value of the Watermelon Seed (Citrullus vulgaris Schrod.). Journal Science of Food Agriculture, 26(5):843-854.

Sadiq, I. S. Duruminiya, N. I. Balogun, J. B. kwada, D. and Izuagie, T (2016). Nutritional and Anti-nutritional Value of Tamarind Fruit (Tamarindus indica). International Journal of Applied Research and Technology.5 (3);50-56.

Sadiq, I. S., Izuagie, T., Shuaibu, M, Dogoyaro, A. Garba and Abubakar, S. (2013). The Nutritional and Medicinal Value of Date Palm (Phoenix dactylifera). International Journal of Modern Chemistry.4 (3):147-154.

Soforowa, A. (1984). Medicinal plants and traditional medicine in Africa, John Wiley and sons, pp 112-142

Teotia, M.S.and Ramakrishna, P (1984). Chemistry and technology of melon seeds. Journal of Food Science and Technology 21, 332 - 340.

Wani, A.A., Sogi, D.S., Wani, T.A and Shivhare, U.S. (2011). Characterization and functional properties of watermelon (Citrullus lanatus) seed proteins. Journal of the Science of Food and Agriculture 91, 113 - 121. 